\title{
Nuances of Compulsory Land Acquisition and Compensation in Botswana: The Case of the Pitsane-Tlhareseleele Road Project
}

\author{
Nametso Lekgori 1, Partson Paradza 2, and Innocent Chirisa 3 \\ 1-2 Department of Real Estate, BA ISAGO University, Botswana. \\ 3 Department of Rural and Urban Planning, University of Zimbabwe.
}

To cite this article: Lekgori, D.N., Paradza, P. \& Chirisa, I. (2020). Nuances of Compulsory Land Acquisition and Compensation in Botswana: The Case of the Pitsane-Tlhareseleele Road Project. Journal of African Real Estate Research, 5(1), pp.1-15. DOI: 10.15641/jarer.v5i1.811.

\begin{abstract}
For years compensation has been awarded for compulsory land acquisition in Botswana and land acquisition for infrastructure projects is typically accompanied by dissatisfaction by displaced families. This is particularly the case on communal/customary land where affected parties tend to have an unclear understanding of the legal procedures that govern and inform acquisition and compensation. Often these issues of dissatisfaction relate to the misinterpretation of the legal frameworks. However, limited research has been conducted to examine the perceptions of the displaced persons and the expropriating authority as to the adequacy of the compensation payment. Therefore, it is necessary to understand how they are interpreted by each party to identify how they can be improved to better align with both parties. This paper seeks to examine the views of both the affected persons (occupying customary land) as well as the expropriating authorities (expropriating the land) in a bid to inform policy and practice, and to contribute to existing debates on compensation for expropriation. A case of the Pitsane-Tlhareseleele road project where portions of land were expropriated from customary land holders was used. Data were collected through key informant interviews and document analysis. The results of this study revealed differences between the perceptions of affected people and those of the expropriating authority. Government officials believed that the compensation offered was satisfactory, as everything was prepared in keeping with the provisions of the law. However, the affected persons were of the view that the compensation they received was not satisfactory, even though the compensation was paid in accordance with the existing statutory framework. The study concluded that this difference in perception emanates from the use of different yardsticks to measure adequacy. These differences in perception could be minimised if the existing statutes are amended to make it mandatory for the affected people to be actively involved in the property valuation process.
\end{abstract}

Keywords: Compulsory Land Acquisition; Expropriation Policy; Compensation Adequacy; Customary Land; Botswana 


\section{Introduction}

Lewin (2011) opines that Botswana is one of the fastest-growing economies in Southern Africa, as indicated by its high per capita income increase from USD \$80, when the country attained independence in 1966, to USD \$6,924 in 2016 (United Nations Development Programme [UNDP], 2009; Honde \& Abraha, 2017). Since gaining its independence in 1966, Botswana managed to turn its economy from a low-income into a middle-income country (UNDP, 2009). This economic development has also been characterised by the compulsory acquisition of properties in terms of Section 8 of the Constitution of 1966, read together with Section 3 of the Acquisition of Property Act (Chapter 32:10) (APA) of 1955, and Section 33 of the Tribal Land Act (Chapter 32:02) of 1966. Adams et al. (2003) pointed out that when Botswana commercialised the livestock industry through the Tribal Grazing Land Policy of 1975 and the National Policy of Agricultural Development of 1991 it displaced a number of customary land holders. This practice has continued into other economic sectors.

The 2002 land policy review highlighted that there are wide differences in compensation between displaced people from freehold and those from customary land. Those displaced from customary land receive far less compensation as compared to those displaced from freehold properties (Adams et al., 2003). These differences are attributed to the differences in statutory provisions of the Tribal Land Act (which guides compensation for customary land) and the Acquisition of Property Act (Adams et al., 2003; Department of Roads, 2008). According to the Department of Roads (2008:12), "Land boards have argued that since tribal land is free, it is impossible to quantify, in monetary terms, loss of rights to use a particular piece of land beyond unexhauseted improvements on it..." Many large projects in Botswana (such as the construction of Maun Airport) have compulsorily acquired land and has led to the displacement of hundreds of families living on customary land.

There is consensus that when real estate is expropriated, a fair or just compensation should be paid to the affected persons (Ambeye, 2009; Alemu, 2012; Sellke, 2012; Nikiema, 2013). The underlying principle of compensation is that no one should become impoverished for public benefit and that any affected person should be paid for the loss he/she was forced to incur. Although legal provisions stipulate that fair compensation has to be paid, it is noted that inadequate compensation is among the chief causes of compensation disputes (Ambaye, 2009; Alemu, 2012). Nikiema (2013) has pointed out, in this regard, that the valuation method has a significant impact on the compensation value. Unjust compensation may also be associated with delayed payment, disregarding some compensable items during inspection, and using arbitrary compensation rates (Kakulu, 2008; Ndjovu, 2016). Major challenges associated with compensation for expropriated real estate, especially in Africa, include inadequacy of compensation, delays in payment of compensation, and the lack of professional valuers used for compensation purposes (Alemu, 2012; Chimbetete, 2016; Mutema, 2019). 
This paper seeks to examine the views of affected persons and the expropriating authorities in a bid to inform policy and practice as well as contribute to existing debates on compensation for expropriation. It is important to understand the perspectives of both parties because, often the issues relate to the misinterpretation of the legal frameworks. Therefore, it is necessary to understand how they are interpreted by each party to identify how they can be improved to better align with both parties. A case study of Pitsane-Tlhareseleele road project was chosen for this research as it is the most recent example of compulsory acquisition of communal land. The project falls under the Good Hope District Council on the South-East border of Botswana. The project was the construction of a $5.25 \mathrm{~km}$ long road and acquired close to $1,400 \mathrm{~m} 2$ of land. This resulted in the displacement of 22 households. Data were collected through semistructured interviews.

\section{Literature Review}

This section begins by discussing the theories relevant to the paper and thereafter reviews past research in a bid to identify the gaps in the literature.

\subsection{Theoretical Framework}

Compensation for expropriation is based on two theories: the Equity and Equivalence Theory and the Takers' Gain Theory (Kabanga \& Mooya, 2018). According to Mugisha (2015), the Equity and Equivalence Theory is also known as the Indemnity Theory or the Owner's Loss Theory. This theory was developed in the United Kingdom through the Lands Clauses Act of 1845 (Denyer-Green, 2013); and is generally accepted in international case law (Vig \& Gajinov, 2016). The Equity and Equivalence Theory is the dominant principle in most legal frameworks guiding compensation for compulsory acquisition of land across the world (Ambaye, 2009, 2013; Mugisha, 2015).

The theory of Equity and Equivalence is based on the principle that affected owners and occupants should neither be enriched nor impoverished as a result of the compulsory acquisition of their property (Viitanen, 2002; Asian Development Bank, 2007; Keith et al., 2008; FAO, 2009; Viitanen et al., 2010; Deeyah \& Akujuru, 2017; Kabanga \& Mooya, 2017). The main objective of this theory is to place the affected person in the same position as he/she was before the property was compulsorily acquired (Ambaye, 2009; Keith et al., 2008; Ambaye, 2013; Pai \& Eves, 2016). In other words, no one is supposed to benefit from the government's quest to take property for public benefit, but in the same vein, no private individual should be disadvantaged simply because the government needs this property for the benefit of the public. In effect, the theory of Equity and Equivalence is aimed at providing dispossessed groups with adequate financial compensation (Mahalingam \& Vyas, 2011). The aim of this theory is not only to compensate for tangible losses, but also to provide compensation for intangible losses which include disturbance, solatium, severance and injurious affection (Pai \& Eves, 2016; Kabanga \& Mooya, 2018; Pai, 2019). The guiding assumption is that the affected person is supposed to purchase a similar property on the market using the compensation he/she received for the expropriated property (Ambaye, 
2013; Denyer-Green, 2013). Property valuation for the subject property is based on its development potential use and not on its current use when compensation is based on the Indemnity Principle (Denyer-Green, 2013).

It is also important to note that contrary to the principle of Equity and Equivalence, the Taker's Gain principle can also form the foundation for compensation (Mugisha, 2015; Kabanga \& Mooya, 2017; Kabanga \& Mooya, 2018). The Taker's Gain Theory is based on the principle that the expropriating authority is supposed to pay for what it gained from the affected person. In this case what the expropriating authourity is gaining is land and nothing more (Ambaye, 2013). As such intangible heads of claim which are compensable under the Equity and Equivalence Theory, including disturbance allowance, solatium, severance and injurious affection, are disregarded (Kabanga \& Mooyer, 2018; Pai, 2019). Only the market value of the expropriated property is a compensable head of claim under the Taker's Gain Theory (Ambaye, 2013). The Taker's Gain Theory, which is used in China, is based on the principle that payment of any claims which are not gained by the expropriating authourity drains public resources. Under the Taker's Gain principle, property valuation for expropriation is based on the current use unlike the development potential of the subject property which is used in the Equity and Equivalence Theory (Ambaye, 2013).

In view of the above discussion, the legal framework guiding property valuation for expropriation in Botswana appears to be based on the Equity and Equivalence Theory. This is based on the fact that heads of claim as provided by Section 33 of the Tribal Land Act and Section 16 of the Acquisition of Property Act include other factors other than the expropriated land like injurious affection and cost of resettlement. It is important to note that customary land is not considered under compensable heads of claim in terms of Section 33 of the Tribal Land Act. It is therefore important to have a discussion on customary land.

\subsection{Compensation for Customary Land}

The communal land tenure system is also known as the tribal or customary land tenure system. Unlike the freehold tenure system where individuals have ownership rights, under the communal land tenure system individuals enjoy use rights (Mutema, 2003), as the land belongs to the community. In most cases communal land is administered by community leaders (Adams, Kalabamu \& White, 2003; Kalabamu, 2019) and only members of a certain community have use rights which can be passed from one generation to the other (Nsoh, 2018). Wily (2018) pointed out that most of the communal land rights are not formally registered through the modern cadastral system. According to Adams et al. (2003), customary land is not considered as a commercial asset on the grounds that it is given for free.

Information is not easily available in communal land because property ownership and use rights are not formally documented (Kabanga \& Mooya, 2018; Pai, 2019). The customary land tenure system, where land is not considered to be a commercial commodity, makes it incompatible with 
market value standards (Pai \& Eves, 2016; Kabanga \& Mooya, 2017, 2018; Makathimo, 2019). According to Pai (2019), the use of market value for customary properties results in undervaluation due to the fact that its unique cultural value does not conform to market value standards. Kabanga and Mooya (2018) recommended for further research to come up with more appropriate valuation standards for communal land which is not based on market value principles. This recommendation was supported by Pai (2019) who pointed out that when customary land is expropriated, it is not just the land in its physical nature which is expropriated, but this includes both tangible and intangible assets associated with that land. Existing valuation methods do not take into consideration the value of intangibles which include sentimental attachments, proximity to neighbors or relatives, spiritual sites, aesthetic qualities and customer goodwill (World Bank, 2004). These intangibles are dicarded because it is difficult to estimate their value objectively.

Usually when communal land is expropriated, land is not considered to be among the compensable heads of claim based on the notion that land holders do not own the land but only have use rights (Tagliarino, 2017; Wily, 2018). Scholars like Sheehan (2002) and Tagliarino (2017) challenged this notion on the view that because communal land is not legally registered using the modern land registeration system it does not disqualify land holders to be owners of their land. They opined that displaced persons must be compensated for their land as well. Sheehan (2002) recommended that statutes must provide for compensation of communal land since land holders have use rights. In some cases communal land holders are ignorant of the statutory provisions guiding expropriation and compensation of their land (Kusiluka et al., 2011; Kabanga \& Mooya, 2018; Grover, 2019). Good governance in expropriation and compensation calls for the expropriating authourities to make sure that affected persons understand statutory provisions guiding expropriation. There must be a statutory provision which makes it mandatory for displaced people to get professional advise where necessary at the expense of the expropriating authourity (FAO, 2008).

From the above discussion, it can be inferred that generally there is no compensation for customary land as it is considered to be a free commodity. It can also be noted that market value principles do not take into consideration intangible value which is a key characteristic of customary land. Furthermore, information on customary land tenure is not easily available since land rights are passed from one generation to the other orally. As such, market based valuation methods as well as conventional legal frameworks for compulsory acquisition might not capture adequately the loss of the displaced customary land holders.

\section{3 Review of Past Studies}

Over the years, there has been an increase in literature on the issue of adequacy of compensation offered for expropriated properties across the world. Studies have been undertaken in different countries using different approaches. Alias and Daud (2006) for example, carried out a study on the 
adequacy of compensation paid for expropriated properties in Malaysia. They benchmarked existing legal frameworks guiding compensation in Malaysia with the statutes of other countries and concluded that there are gaps in the country's existing framework. Further, they recommended the adoption of international best practices as a way of addressing the issue of adequacy in compensation. Komu (2014) also carried out a case study on the adequacy of compensation paid for expropriated properties in Tanzania, collecting data through interviews, document analysis and workshops. This study concluded that different stakeholders do not have a common understanding of the entire compensation process. Kusiluka et al. (2011) noted differences in perceptions between diplaced persons and expropriating authourities when it comes to the adequacy of the compensation paid in Tanzania. Similar studies were done by Alemu (2012) and Ambaye (2009) in Ethiopia. These scholars also used a case study approach and collected data through the questionnaire surveys, interviews, field observations and document analysis. Primary data were collected from displaced peoples and the study concluded that a better understanding of the legal framework guiding compensation for expropriation could lead to adequate compensation settlements in future.

In Nigeria, Kakulu (2008), and Deeyah and Akujuru (2017) also carried out case studies on the adequacy of compensation paid for expropriated properties. In each case, data were collected through focus group discussions, interviews, questionnaires and document analysis. These scholars concluded that the compensation offered by the expropriating authorities was not adequate to indemnify the affected people. In Zimbabwe, Chimbetete (2016) and Mpofu (2019) used the case of farms expropriated during the fast-track land reform programme to assess the adequacy of the compensation paid. They collected data through document analysis, key informant interviews and focus group discussions. These studies noted differences in the definitions of adequate compensation advanced by former commercial farmers and government authorities. They recommended the amendment of existing legal frameworks that guides compensation for expropriation and the development of a system which accommodates consensus-based compensation. The need to amend current statutes guiding compulsory acquisition and compensation in Zimbabwe is inline with international best practice which was also echoed by Paradza, Yacim and Zulch (2019).

From the reviewed literature, one can extract that affected people are of the view that the compensation offered for their expropriated properties is inadequate. Many of the issues around inadequate compensation gravitate around unclear legal frameworks and the misunderstanding or misinterpretation of these legal frameworks for compensation. However, it is can also be noted that issues around inadequate compensation vary in different contexts.

From the foregoing, it can be noted that although there are several studies on the adequacy of compensation paid in compulsory property acquisition, empirical studies focusing on Botswana are limited. Those that exist have only partially focused on compensation adequacy. Ng'ong'ola (1989), for example, used the case study approach to analyse property valuation for 
expropriation in Botswana and collected data through document analysis. A recent study done by Mengwe (2019) was based on a review of statutes guiding compensation for expropriation in Botswana. Both studies did not examine the perceptions of both the affected people and the expropriating authorities involved in land acquisition. Furthermore, since Ng'ong'ola's (1989) study was carried out three decades ago, things might have changed in the intervening years. Ng'ong'ola also focused on expropriated freehold properties without considering communal land. The present study seeks to bridge this gap in knowledge by analysing the perceptions of the expropriating authority and affected persons on the adequacy of the compensation paid for expropriated customary properties based on recent data. It is important to understand the perspectives of both parties because often the issues relate to the misinterpretation/misunderstanding of the legal frameworks. Therefore it is necessary to understand how they are interpreted by each party to identify how they can be improved to better align with both parties.

Recent expropriation projects in Botswana include the Botswana Integrated Transport project which resulted in the displacement of 191 households on land acquired compulsorily (Department of Roads, 2008), while the construction of the Maun Airport resulted in the relocation of 256 families. Previous studies noted that compensation for expropriation in Botswana is biased towards freehold property owners whilst customary land holders receive much less compensation (Adams et al., 2003). These compensation disparities emanate from differences in compensable heads of claim which are provided by the Tribal Land Act and the Acquisition of Property Act.

\section{Methodology}

A case study approach was adopted based on the Pitsane-Tlhareseleele road project. Evidence from previous studies indicates that the case study approach is the most appropriate for conducting research on the adequacy of compensation paid for expropriated properties. This is shown by the fact that all reviewed literature adopted the case study approach, albeit with different data collection methods, including field observation, document analysis, keyinformant interviews and questionnaire surveys.

The case study area falls within the boundaries of the Good Hope District Council and is administered by Rolong Land Board. The PitsaneThareseleele road project covers a stretch of $5.25 \mathrm{~km}$ and was constructed by the government of Botswana in partnership with the World Bank using Output and Performance-Based Road Contracting (OPBRC). OPBRC is a type of public-private partrnership where contracts for road construction or maintenance are given to private actors and fixed payments are made when performance levels are met. There is a provision for payment reductions in the event of noncompliance with set performance levels (Radović et al., 2014). A total of 22 people lost part of their communal land to make way for the construction of the road. This project was used as a case study because it is one of the recent projects where affected communities have already been compensated for expropriated customary/tribal land. This sets affected people 
in a better state to assess the adequacy or inadequacy of the compensation offered, unlike in cases where the outcome of compensation is inconclusive. Primary data were collected through guided interviews. An interview guide with semi-structured questions was used during interviews. Interviews were preferred because they allowed the researcher to probe further as a way of seeking clarity on the responses given to the research questions. Respondents were questioned on matters relating to the perceived adequacy of the compensation paid. Furthermore, questions relating to their interpretations of the process of acquisition and compensation that directly related to the case study project were asked. A total of 22 displaced people and eight planning officers were interviewed; four from the Rolong Land Board and four from the Good Hope Council. The Good Hope Council is one of the rural local authorities in Botswana. The Good Hope Council Council, like other rural local authourities, has a mandate to provide local governance. It is important to note that rural local authourities in Botswana do not have powers to administer customary land, such powers are vested on Land Boards by Section 13 of the Tribal Land Act of 1970. The Rolong Land Board is responsible for administering customary land which falls within the bounderies of the Good Hope Council's jurisdiction. Secondary data were also used through the review of letters and official reports about the PitsaneTlhareseleele road project. The results of this study are discussed in the following section.

\section{Results}

The results of this study are divided into two subsections as follows: Section 4.1 focuses on the perceptions of government officials and Section 4.2 discusses the perceptions of the affected persons about the adequacy of the compensation paid.

\subsection{Adequacy of Compensation Paid: Government Perspective}

It was observed that both key informants from the two local authorities (Good Hope Council and Rolong Land Board) were of the view that the compensation paid to the affected people was adequate as it was calculated in accordance with the requirements of Section 33 of the Tribal Land Act of 1970.

One of the interviewed expropriating authorities highlighted that during the project, there were consultations between the Land Board, the community and other stakeholders through meetings that were held at Pitsane and Thareseleele on different dates. The Land Board requested a meeting to inform the affected people about the expropriation and their rights in relation to this matter. The views of the affected communities were documented and taken into consideration prior to the expropriation phase. Another respondent stated that the acquiring authority, with the assistance of the Land Board, made a reasonable effort to identify and contact all occupiers within all zoned areas. However, a few individuals, who did not live on their land and did not have relatives in the area, were not aware that the land had been acquired. This goes against the principle of transparency, which was emphasised by 
Food and Agriculture Organisation (FAO) $(2008 ; 2017)$ and requires that the expropriating authority does everything within its powers to inform and engage all affected persons. In order to protect the affected people, especially vulnerable members of the community, the expropriating authority should have identified all people with interests in the subject properties and sought their views during the planning stage.

It was also established from four other research respondents that when the decision was made to proceed with the project, the compensation assessment committee (consisting of members from the Council and Land Board) conducted a physical inspection of the affected properties, recording the details of all improvements to the land and any other fixed assets affected within the zoned area. As highlighted before, 22 households were affected, and portions of their land were taken for road development purposes. The recorded details of improvements on land included the type of building materials used, size, location, owner and approximate age. Respondents reiterated that after the assessment, the committee invited interested parties to verify the captured data and to raise any queries or objections to the committee. According to several interviewees, the Department of Lands submitted the valuation report to the acquiring authority for compensation soon after the completion of the valuation exercise. In terms of Section 33(2) of the Tribal Land Act (Chapter 32:02) of 1970, the compensable heads of claim for customary land should include the value of standing crops, improvements on the land, resettlement costs and the loss of right of land use. In this particular case, the affected persons were not resettled since just a portion was acquired, hence it was believed that the remainder was economically productive. Document analysis revealed that the compensation authority managed to capture the relevant details stipulated in the Tribal Land Act which includes details about existing crops and improvements on land. However, it is worth noting that only a portion of the land was expropriated, but the Tribal Land Act is silent on how severance is supposed to be calculated when only a portion of land is acquired. Therefore, an assessment of whether the severance was calculated as provided by law could not be easily undertaken.

From the above discussion it can be inferred that the in the view of officials from the expropriating authourity that the compensation paid was adequate as it was administered in line with the provisions of the Tribal Land Act. In this case, compensation claims which are outside what is stipulated by the law becomes illegal and therefore it is not considered. In the view of government officials in cases which include compensation for communal land, the Tribal Land Act must be used as a yardstick to measure adequacy. In this view, only heads of claim which are prescribed in the Tribal Land Act are compensable. This shows a gap between the law and the expectations of the people. If this gap continues to remain unadressed whilst affected people are not satisfied it can spoil the relationship between the expropriating authourities and affected people. Any form of conflict between the expropriating authourities and affected communities can delay the completion of projects, creating broader economic repercussions. 
Having discussed the views of government officials on the adequacy of the compensation paid, to provide a balanced investigation into compensation requires that the views of affected people are considered. The next section therefore focuses on the perceptions of the affected people about the adequacy of the compensation paid.

\subsection{Adequacy of Compensation Paid: Views of Displaced Persons}

Interviews with affected persons revealed that the affected people felt the compensation paid was not adequate since certain factors that they believed they were entitled to compensation for were disregarded. Most of the affected people complained about non-compensation for disturbance and were of the view that they were supposed to be compensated for disruptions in electricity and water services as well as the widespread dust, smoke and disruptions in the irrigation and drainage systems in the area. Another interviewee lamented that:
"property valuation for expropriation for this project was shrouded in obscurity. We were not involved during the time when our properties were assessed for compensation."

Moreover, all the affected people confessed that they were not familiar with the statutes guiding compulsory acquisition and compensation in Botswana. This was also compounded by the relative lack of professional valuers, who could have proffered impartial advice to the dispossessed people. As noted by Mutema (2019), property valuers in the Southern African Development Community (SADC) region are so scarce that the costs of valuation services are likely to be beyond the reach of most rural subsistence farmers.

Although most of the affected people were not satisfied with the compensation offered, only one person challenged the compensation offered in terms of Section 33(3) of the Tribal Land Act in court. This person lost the case. As highlighted before, none of the respondents were aware of the legal provisions guiding compensation for expropriation. As such, it is very likely that people might not have known that they could challenge the compensation offered.

\section{Discussion}

From the results of this study, it can be deduced that professionals and affected persons have different perceptions about the adequacy of compensation offered for expropriated communal properties. Differences in perception on compensation between affected persons and expropriating authourities were also noted by Komu (2014) and Kusiluka et al. (2011). In the eyes of the professionals, provisions of the Tribal Land Act must be used as a yardstick to measure adequacy. On the other hand, affected persons do not make reference to the Tribal Land Act, but on their subjective assessment of adequate compensation. Table 1 summarises the principal views expressed by different interviewees. 


\section{Table 1: A Matrix Indicating the Principal Views from Various Organisations}

\begin{tabular}{|l|l|}
\hline Respondent & Major view(s) \\
\hline $\begin{array}{l}\text { Government } \\
\text { officials }\end{array}$ & $\begin{array}{l}\text { The expropriation was carried out in line with the provisions of } \\
\text { the law. People were consulted prior to and during the } \\
\text { expropriation and compensation process. Objections were } \\
\text { considered and the government did everything within its powers } \\
\text { to identify and engage all relevant stakeholders. }\end{array}$ \\
\hline Displaced persons & $\begin{array}{l}\text { The compensation offered was not adequate and affected persons } \\
\text { were not part of the assessment process. They were not aware of } \\
\text { the legal framework guiding compensation for expropriated } \\
\text { properties. Displaced persons perceived the compensation process } \\
\text { that is provided by the legislation to be unfair. }\end{array}$ \\
\hline
\end{tabular}

As shown in Table 1, affected people and government officials have different views about the adequacy of the compensation offered. Key informants, namely government officials, were of the view that the expropriation and compensation process was undertaken as prescribed by the law. However, displaced persons sang a different tune. For them, even if the compensation was done in accordance with the provisions of the law, it could not be classified as adequate. The general perception of affected people was that the compensation offered was not adequate since they were not compensated for loss caused by disturbances like noise and dust which are not provided in statutes.

In the eyes of the professionals, the success of a compensation programme lies in the legality of the process, whereas the affected people are of the opinion that it depends on whether the relevant authorities have taken their views into consideration. Furthermore, affected parties are not privy to the legal framework of compensation and few attempts were made by authorities to bring them along in the process and help them understand. This leaves the displaced parties vulnerable to being exploited. Professionals, on the other hand, are well versed with the legal provisions and laws pertaining to land acquisition and compensation. It can be noted that the authorities do make the effort to make sure they follow the legal guidelines but do so in a way to 'tick boxes' manner rather than making it a fair and transparent process where both parties are satisfied and have equal knowledge and understanding of the process. Kusiluka et al., (2011) also found similar findings in Tanzania.

\section{Conclusion, Policy Options and Recommendations}

This study used structured interviews to measure the perceptions of affected persons and expropriating authorities on the adequacy of compensation offered for expropriated properties pertaining to the Pitsane-Tlhareseleele Road Project. From the findings of this study it can be concluded that the affected people and the professionals leading the expropriation process were not reading from the same page. The authorities followed the legal framework without using further judgement or consideration to the complexities of removing people from customary land. This was coupled by the fact that the affected people had very little understanding of the legal framework and 
procedures around compensation. As a result, the two parties had contrasting perceptions regarding the legitimacy and adequacy of the compensation paid for the land used for the road project.

In view of the findings of this paper, it is recommended that there is a need to educate communities about the provisions of legislation on compulsory acquisition and compensation. Furthermore, there is a need for more research with the view of developing a valuation approach that is guided by both statutory and customary law and is acceptable and appropriate for the affected people living on customary land. The limitations of this study include that it could have used an independent valuer to assess the fairness of compensation offered for expropriated properties. Also, this study was based on a single case study, it is recommended that the same study can be replicated in future using a multiple case study approach.

\section{References}

Adams, M., Kalabamu, F. \& White, R. (2003). Land tenure policy and practice in Botswana: Governance lessons for Southern Africa. Journal fur Entwicklung Spolitik, 19(1), pp.55-74.

Alemu, B.Y. (2012). Expropriation, valuation and compensation practice in Amhara National Regional State (ANRS) - The case of two cities (Bahir-Dar and Gonder). Nordic Journal of surveying and Real Estate Research, 9(1), pp.30-58.

Alias, A. \& Daud, M.N. (2006). Payment of adequate compensation for land acquisition in Malaysia. Pacific Rim Property Research Journal, 12(3), pp.326-349.

Ambaye, D.W. (2009). Land valuation in Ethiopia: Valuation methods and adequacy of compensation. A paper presented the 7 th the International Federation of Surveyors (FIG) regional conference. October 19-22, Vietnam. pp.1-38.

Ambaye, D.W. (2013). Land rights and expropriation in Ethiopia. Unpublished PhD thesis, Stockholm, Royal Institute of Technology.

Asian Development Bank (2007). Compensation and valuation in resettlement: Peoples Republic of China.

Chimbetete, I.H. (2016). Final report for capacity needs assessment for the valuation of immovable improvements on acquired farms. United Nations Development Programme (UNDP).

Deeyah, C.L. \& Akujuru, V.A. (2017). Investigating the Sufficiency of Paid Compensation for Compulsory Acquisition in Road Infrastructural Provision in Rivers State. Research on Humanities and Social Science 7(2), pp.20-27.

Department of Roads, (2008). Resettlement Policy Framework final report. Goborone, Ministry of Works and Transport, Government of the Republic of Botswana.

Denyer-Green, B. (2013). Compulsory purchase and compensation (10th Edition). London and New York: Routledge. 
Food and Agriculture Organization (FAO). (2008). Compulsory acquisition of land and compensation: Land tenure studies 10. Rome: Food and Agriculture Organisation of the United Nations.

Food and Agriculture Organisation. (2009). Land tenure studies 10. Compulsory acquisition of land and compensation. Rome: Food and Agriculture Organisation of the United Nations.

Government of Botswana. (1955). Acquisition of Property Act (Chapter 32:10). Gaborone, Government of Botswana.

Government of Botswana. (1966). Constitution of Botswana. Gaborone, Government of Botswana.

Government of Botswana. (1970). Tribal Land Act (Chapter 32:02). Gaborone, Government of Botswana.

Government of Botswana. (2013). Local Government Act (Chapter 40:01). Gaborone, Government of Botswana.

Grover, R. (2019). Compulsory purchase in developing countries. In Plimmer, F, and McCluskey, W. (eds) 2008. Routledge Handbook of Contemporary Issues in Expropriation. Routledge: London and New York. pp.1-29.

Honde, G. \& Abraha, F.G. (2017). Botswana. African Economic Outlook 2017, pp.9.

International Valuation Standards Council, (2016). International valuation standards. London, International Valuation Standards Council.

Kabanga, L. \& Mooya, M.M. (2017). Assessing compensation for customary property rights in Malawi: The case of Mombera University project. African Journal of Rural Development, 2(4), pp.483-496.

Kabanga, L. \& Mooya, M.M. (2018). Compensation theories and expropriation of customary property rights: A Critical Review. Journal of African Real Estate Research, 3(2), pp.87-106.

Kakulu, I.I. (2008). An Analysis of processes and methods in compulsory land acquisition and compensation in Nigeria. Doctoral dissertation, University of Reading.

Kalabamu, F.T. (2019). Land tenure reforms and persistence of land conflicts in Sub-Saharan Africa:The case of Botswana. Land Use Policy, 81, pp.337-345.

Keith, S., McAuslan, P., Knight, R., Lindsy, J., Munro-Faure, P., Palmer, D. \& Spannenberg, L. (2008). Compulsory acquisition of land and compensation. In: Food and Agriculture Organisation, 2008. Land Reform: Land Settlement and Cooperatives, pp.7-16. Rome: Food and Agriculture Organisation.

Komu, F. (2014). Conceptualizing fair, full and prompt compensation - the Tanzanian context of sustaining livelihood in expropriation projects. Journal of Land Administration in Eastern Africa, 2(2), pp.252-267.

Kusiluka, M.M., Kongela, S., Kusiluka, M.A., Karimuribo, E.D. \& Kusiluka, L.J. (2011). The negative impact of land acquisition on indigenous communities' livelihood and environment in Tanzania. Habitat International, 35(1), pp.66-73.

Lewin, M. (2011). Botswana's success: Good governance, good policies, and good luck. Yes, Africa Can, 81.

Makathimo, M.K. (2019). Valuation of unregistered community land in Kenya - addressing the fundamentals. In proceedings of The 19th 
African Real Estate Society Annual Conference. 10-13 September 2019, Arusha, Tanzania. pp.319-335.

Mengwe, D. (2019). Compensation for expropriation in Botswana: Issues and transformative suggestions. Pimer, F. \& McCluskey, W. (eds). 2019. Routledge Handbook of Contemporary Issues in Expropriation London and New York: Routledge. pp.352-378.

Mpofu, R. (2019). An investigation of the valuation methodology for compensation of former white owned farms in Zimbabwe: A case study of Seke and Goromonzi District. Unpublished Bachelor of Science Honours Real Estate Management Dissertation, Harare, University of Zimbabwe.

Mutema, M. (2003). Land Rights and Their Impacts on Agricultural Efficiency, Investments and Land Markets in Zimbabwe. International Food and Agribusiness Management Review, 6(2), pp.50-64.

Mutema, M. (2019). The valuation profession and compulsory acquisition and compensation in Africa with special reference to Zimbabwe. In Plimmer, F. \& McCluskey, W. (eds). Routledge Handbook of Contemporary Issues in Expropriation. Routledge: New York. pp.379-397.

Mugisha, J. (2015). Compensation for land expropriation in Rwanda: The need for conventional approaches to valuation. Journal of Land Administration in Eastern Africa, 3(1), pp.296-306.

Mwakapalila, F. \& Henerico, E. (2019). Determinants of land values during compulsory land acquisition in Dar es Salaam: The case of Kinyerezi and Kipawa Wards of Ilala Municipality. International Journal of Science and Research, 8(6), pp.1210-1224.

Ng'ong'ola, C. (1989). Compulsory acquisition of private land in Botswana: The Bonnington farm case. Comparative and International Law Journal of Southern Africa, 22(3), pp.298-319.

Ndjovu, C. (2016). Understanding Causes of dissatisfaction among compensate landowners in expropriation programs in Tanzania. International Journal of Scientific \& Technology Research, 5(1), pp.160-172.

Nikiema, S.H. (2013). Compensation for Expropriation. The International Institute for Sustainable Development: Manitoba, Canada.

Nsoh, W. (2018). The legal status of customary land tenure systems and the protection of communal property in Cameroon. In Xu, T. \& Clarke, A. (eds.). Legal strategies for the development and protection of communal property. In proceedings of The 216 British Academy. 23 May 2016. Oxford University. pp.102-126.

Pai, A. \& Eves, C. (2016). Valuation and equity concerns in customary land takings compensation: the case in Papua New Guinea. In Proceedings of The 22nd Annual Pacific-rim Real Estate Society Conference. 1720 January, Queensland, Australia. pp.1-15.

Pai, A. (2019). Towards a culturally inclusive valuation method for assessing compensation in compulsory acquisition of customary land. Unpublished $\mathrm{PhD}$ thesis, Queensland University.

Paradza, P., Yacim, J. \& Zulch, B. (2019). A critical review of property valuation for expropriation in Zimbabwe. In proceedings of The 19th 
African Real Estate Society Annual Conference. 10-13 September 2019, Arusha, Tanzania. pp 424-449.

Radović, N., Mirković, K., Šešlija, M. \& Peško, I. (2014). Output and performance based road maintenance contracting-case study Serbia. Technical Gazette, 21(3), pp.681-688.

Sellke, A.C. (2012). Property: eminent domain and restoring access to parcels isolated by highway reconstruction: finding the public use-state, Ex.Rel commissioner of Transport V Kettleson. Willim Mitchell Law Review, 39(1), pp.335-372.

Sheehan, J.B. (2002). Towards compensation for the compulsory acquisition of native title rights and interests in Australia. In proceedings of The FAO/USP/RICS Foundation South Pacific Land Tenure Conflict Symposium. 10-12 April, Suva, Fiji. pp.1-46.

Tagliarino, N.K. (2017). The status of national legal frameworks for valuing compensation for expropriated land: an analysis of whether national laws in 50 countries/regions across Asia, Africa, and Latin America comply with international standards on compensation valuation. Land, 6(37), pp.2-29.

United Nations Development Programme. (2009). Assessment of development results: Evaluation of UNDP contribution - Botswana. United Nations Development Programme: Gaborone,.

Viitanen, K. (2002). Just compensation in expropriation? In proceedings of The International Federation of Surveyors (FIG) XXII International Congress. April, Washington, D.C. USA. pp.19-26.

Viitanen, K., Falkenbach, H. \& Nuuja, K. (2010). Compulsory purchase and compensation recommendations for good practice. FIG Commission 9 - Valuation and the Management of Real Estate. Denmark, International Federation of Surveyors (FIG).

Vig, Z. \& Gajinov, T. (2016). The development of compensation theory in international expropriation law. Hungarian Journal of Legal Studies, 57(4), pp.447-461.

World Bank (2004). Involuntary resettlement sourcebook: Planning and implementation in development projects. Washington, DC: The World Bank. 